\title{
Fecundity of Greenland Halibut (Reinhardtius hippoglossoides W.) in the Waters of Iceland
}

\author{
Agnes C. Gundersen ${ }^{1}$, Einar Hjørleifsson ${ }^{2}$, and James Kennedy ${ }^{1}$ \\ ${ }^{1}$ Møreforskning Marine, P.O. Box 5075, 6021 Ålesund, Norway \\ Emails: agnes@mfaa.no,James@mfaa.no \\ ${ }^{2}$ Marine Research Institute, Skulagata 4, Reykjavik, Iceland. \\ Email: einarhj@hafro.is
}

Gundersen, A. C., E. Hjørleifsson, and J. Kennedy. 2009. Fecundity of Greenland Halibut (Reinhardtius hippoglossoides W.) in the Waters of Iceland. J. Northw. Atl. Fish. Sci., 40: 75-80. doi:10.2960/J.v40.m656

\begin{abstract}
It is now considered important to monitor the fecundity of fish stocks as this provides an indication of the Stock Reproductive Potential (SRP). There is currently very little data on the fecundity of the West-Nordic stock of Greenland halibut (Reinhardtius hippoglossoides), which includes Greenland halibut in Icelandic waters. In order to achieve a reference point of fecundity for fish in Icelandic waters, the fecundity was estimated for 48 fish caught in October 1998. Potential fecundity showed a high variation between individuals and was in the range of 8-152 thousand oocytes for fish of 57-99 cm total length. The fecundity - length relationship was Fecundity $=1.942 \times 10^{-3}$ Length $^{3.93}$. The fecundity was compared to previous fecundity estimations for Greenland halibut in other areas. There were significant differences between the estimates for the different areas, however, due to the fecundity being from only a single year, no conclusions on long term differences in fecundity could be drawn.
\end{abstract}

Keywords: fecundity, Greenland halibut, Iceland, Reinhardtius hippoglossoides

\section{Introduction}

Fecundity of the fish within a population is an important component of the Stock Reproductive Potential (SRP) (Lambert, 2008) and is known to vary from year to year and also between stocks of the same species (Bagenal, 1957; Kjesbu et al., 1998; Kennedy et al., 2007). Traditionally, Spawning Stock Biomass (SSB) has been used as a proxy for Total Egg Production (TEP) and SRP, however, TEP is not proportional to the SSB, but affected by the demographical structure of the stock (Marshall et al., 1998). Therefore, the addition of fecundity estimations to other demographic parameters that are already commonly measured for exploited marine fish stocks could allow a more precise measurement of SRP (Lambert, 2008). It has been suggested that this improved measurement of reproductive potential may better reflect a populations recruitment potential (Marshall et al., 1998; Marteinsdóttir and Thorarinsson, 1998; Marshall et al., 2003).

Individual potential fecundity (standing stock of oocytes un-adjusted for atretic losses) varies throughout the maturity cycle (Kennedy et al., 2007). Potential fecundity is at its highest at the end of oocyte recruitment, the fecundity is then down-regulated by atresia. This down-regulation can be over $50 \%$ of the potential fecundity (Kurita et al., 2003). Down-regulation is a commonly occurring phenomenon having being seen in cod (Gadus morhua), herring (Clupea harengus) and plaice (Pleuronectes platessa) (Kurita et al., 2003; Thorsen et al.; 2006; Kennedy et al., 2007). The implication of this is that knowledge on the stage of the ovary development is essential information for meaningful fecundity estimations.

Greenland halibut (Reinhardtius hippoglossoides W.) is a deep sea fish species widely distributed in the north Atlantic, inhabiting depths of $400 \mathrm{~m}$ to about $2000 \mathrm{~m}$ (Boje and Hareide, MS 1993). It is usually found in water masses with a temperature between $-1^{\circ}$ and $4^{\circ} \mathrm{C}$. Despite there being a large fishery on this species little is known about its reproductive biology.

Greenland halibut in Icelandic waters (ICES division Va) are considered part of the West-Nordic Greenland halibut stock. This stock covers areas in the waters 
of East Greenland, Iceland and Faroe Islands (ICES, 2008). The definition has been based on the reporting of a spawning location southwest of Iceland (Magnússon, 1977; Sigurŏsson and Magnússon, 1980). Several investigations on Greenland halibut fecundity are reported. They are however of varying extent. The studies cover West Greenland (Jensen, 1935; Gundersen 2002), East Greenland (Gundersen et al., 2001), Faroe Islands (Gundersen et al., 2002), Barents Sea (Millinsky, 1944; Gundersen et al., 1999, 2000), Southern Labrador Sea (Lear, 1970), Bering Sea (D’yakov, 1978), Southern Labrador and Gulf of St. Lawrence (Bowering, 1980), and the Davis Strait near Labrador (Serebryakov et al., 1992). There however appears to be only one study covering the Icelandic area which was carried out in 1977 and was based on only five fish (Magnússon, 1977).

The aim of this study was to assess the fecundity of Greenland halibut in Icelandic waters in order to get a baseline value for which future studies can be compared. Knowledge on the dynamics of fecundity and reproduction in general is lacking for Greenland halibut. In order to gain a perspective of how this study compares with other estimates of fecundity in Greenland halibut, we compare the data with estimates from other areas.

\section{Material and Methods}

The principal sampling areas for the fecundity analysis were from fish collected west of Iceland, between 64.3-66. $0^{\circ} \mathrm{N}$ and $27.5-29.0^{\circ} \mathrm{W}$ (Fig. 1) and from the north-western slope off Iceland in October 1998. The trawling was conducted at depths between 450-1 $250 \mathrm{~m}$ using a commercial Greenland halibut trawl (Gulltoppur) lined with $40 \mathrm{~mm}$ mesh in the cod end. A total of 48 ovaries from maturing females were collected and preserved at sea in $3.6 \%$ buffered formaldehyde. Additional biological measurements on each female were total length, total weight, gonad and liver weight.

Analyses of potential fecundity were carried out using the method described by Gundersen et al. (1999, 2000). From each ovary a sample of tissue (approximately $0.25-4 \mathrm{~g}$ ) was taken from the middle section of the right lobe of the ovary. Of the three classes of oocytes found in this study only fully vitellogenic oocytes that will be spawned in the next spawning season were counted, these oocytes appear dark when visualized under the binocular microscope. Classification of the oocytes is described by Gundersen et al. (2000). Two sub-samples were counted and used in the fecundity estimates. If the coefficient of variation of the estimates per unit ovary weight was greater than $5 \%$ for the two samples, an additional two samples were counted and

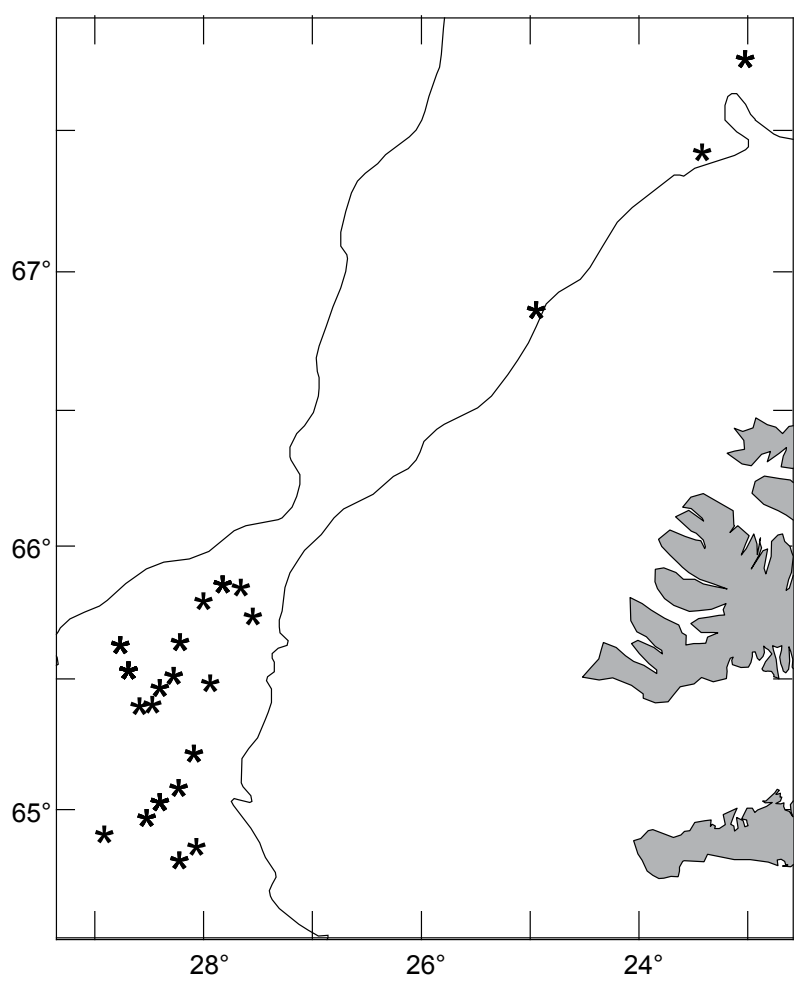

Fig. 1. Sampling locations for Greenland halibut in the 1998 Icelandic October deep water groundfish survey off western Iceland. The line indicates the $500 \mathrm{~m}$ depth contour.

analysed. The sub-sample count ranged from 150 to 1 000 oocytes depending on sample size and maturation. Estimates of the fecundity of each individual female were obtained from the average of the raised sub-sample counts:

$$
\text { Fecundity }=\left(\sum C_{n} O / W_{n}\right) / n
$$

where $C_{n}$ is the counted number of oocytes in sub-sample $n, O$ is the ovary weight, $W_{n}$ is the sub-sample weight and $n$ is the number of sub-samples. Estimation of the parameters describing fecundity of females as a function of length was done on the $\log _{10}$-transformed model:

$$
\log F=a+b \log L
$$

where $F$ is the fecundity and $L$ the total length of each female. The result of the analysis is presented as the untransformed model of:

$$
F=\exp (a) L^{b} .
$$

Bootstrap analysis (5 000 replicates) was done to obtain confidence intervals in the parameter estimates as well as to check for potential bias in the estimates.

A GLM-analyses was conducted to compare the fecundity - length relationship obtained from this study 
TABLE 1. Comparison of fecundity of Greenland halibut with fecundity from other areas showing the area where the fish were caught, year caught, reference of the data, length range of fish in the respective study $(\mathrm{cm})$, fecundity (in thousands) of a 70, 80 and $90 \mathrm{~cm}$ fish calculated from Length-fecundity relationship (missing values indicate that the study did not sample fish of that size), and the $p$-value of the GLM analysis between fecundity from Iceland and the respective area (significant differences were found for six areas).

\begin{tabular}{|c|c|c|c|c|c|c|c|c|}
\hline \multirow[b]{2}{*}{ Area } & \multirow[b]{2}{*}{ Year } & \multirow[b]{2}{*}{ Month } & \multirow[b]{2}{*}{ Reference } & \multicolumn{4}{|c|}{ Fecundity at length } & \multirow[b]{2}{*}{$p$-value } \\
\hline & & & & Length range & $70 \mathrm{~cm}$ & $80 \mathrm{~cm}$ & $90 \mathrm{~cm}$ & \\
\hline Iceland & 1998 & Oct & Present study & $57-99$ & 35 & 59 & 94 & n.a. \\
\hline Hatton Bank & 1999 & Sep & Tuene et al. (2002) & $75-100$ & - & 86 & 118 & $<0.001$ \\
\hline East Greenland & 1997 & Aug & Gundersen et al. (2001) & $63-110$ & 43 & 71 & 110 & $<0.001$ \\
\hline Barents Sea & 1998 & Sep & Gundersen et al. (2000) & $54-95$ & 31 & 52 & 83 & $<0.05$ \\
\hline Faroe Islands & 1998 & May-July & Gundersen et al. (2002) & $63-85$ & 29 & 49 & - & $<0.01$ \\
\hline West Greenalnd & 1998 & Sep-Oct & Gundersen (2002) & $57-107$ & 27 & 44 & 67 & $<0.001$ \\
\hline Iceland & 1977 & Mar & Magnússon (1977) & $66-95$ & 25 & 32 & 39 & $<0.001$ \\
\hline Barents Sea & 1996 & Jul-Aug & Gundersen et al. (1999) & $60-80$ & 35 & 65 & - & $>0.05$ \\
\hline Barents Sea & 1997 & Aug-Oct & Gundersen et al. (2000) & $52-91$ & 29 & 55 & 97 & $>0.05$ \\
\hline
\end{tabular}

to each of the fecundity - length relationships obtained from other areas, as reported by other authors (see respective areas and references in Table 1), in order to study how fecundity of Greenland halibut in Icelandic waters relates to other geographical areas.

Gonadosomatic index (GSI), which indicates state of maturity of the female gives the proportion of ovary with respect to the total weight. GSI was estimated using equation:

$$
G S I=100 \mathrm{GW} /(T W-G W)
$$

where $G W$ is the gonad weight and $T W$ is the total weight of the female, both in grams.

\section{Results}

Gonadosomatic index (GSI) (Fig. 2) was mainly in the range $1-8 \%$ with one high value of $13 \%$. Potential fecundity varied between 8-152 thousand oocytes for fish ranging in size from $57-99 \mathrm{~cm}$ (Fig. 3). The relationship that describes fecundity as a function of length $\left(n=48, r^{2}=0.69, p<0.001\right)$ is:

$$
\log \text { Fecundity }=-2.71+3.93 \log \text { Length }
$$

or as a power function:

$$
\text { Fecundity }=1.942 \times 10^{-3} \text { Lengt }^{3.93}
$$

Confidence interval of the parameter estimates as determined by bootstrapping is presented in Table 2. The results show that the median bootstrap estimates are the same as those estimated by linear regression, indicating that there is no bias in the parameter estimation.

\section{Comparisons with other estimates}

The fecundity-length relationship from the present study was compared to Greenland halibut from other areas using log-transformed data and ANCOVA with length as the covariate. The relationships indicated that Greenland halibut caught in Icelandic waters had a lower potential fecundity than Greenland halibut caught off East Greenland in 1997 and Hatton Bank in 1999 and a higher fecundity than Greenland halibut in Faroe Islands in 1998, West Greenland in 1998, Barents Sea in 1998, and Iceland in 1977. The fecundity was not significantly different from Greenland halibut caught in the Barents Sea in 1996 or 1997 (Table 1). Even though the fecundity was statistically significant, it can be seen from the average values for fish of a specific length in each area and the spread of the fecundity data in Fig. 3, that there is a large overlap in the fecundity of individual fish in different areas.

\section{Discussion}

The reproductive biology of the Greenland halibut is poorly understood, and especially in regards to the West-Nordic stock which includes Greenland halibut in the waters of Iceland. There appears to be only one previously documented study of fecundity in Iceland, which consisted of only five fish (Magnússon, 1977). The present study is thus intended as a baseline for further studies. Population potential fecundity is known to vary both between stocks/areas of the same species (Bagenal, 1966; Witthames et al., 1995; Kennedy et al., 2007) and also between years of the same stock (Kjesbu 


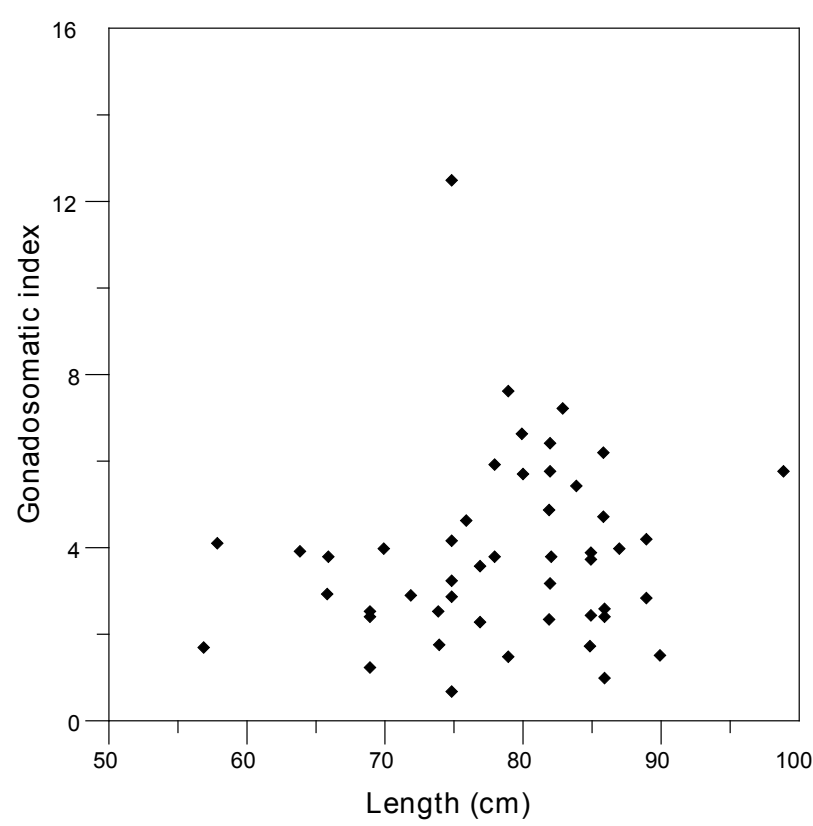

Fig. 2. Gonadosomatic index displayed against length for Greenland halibut females caught in Icelandic waters.

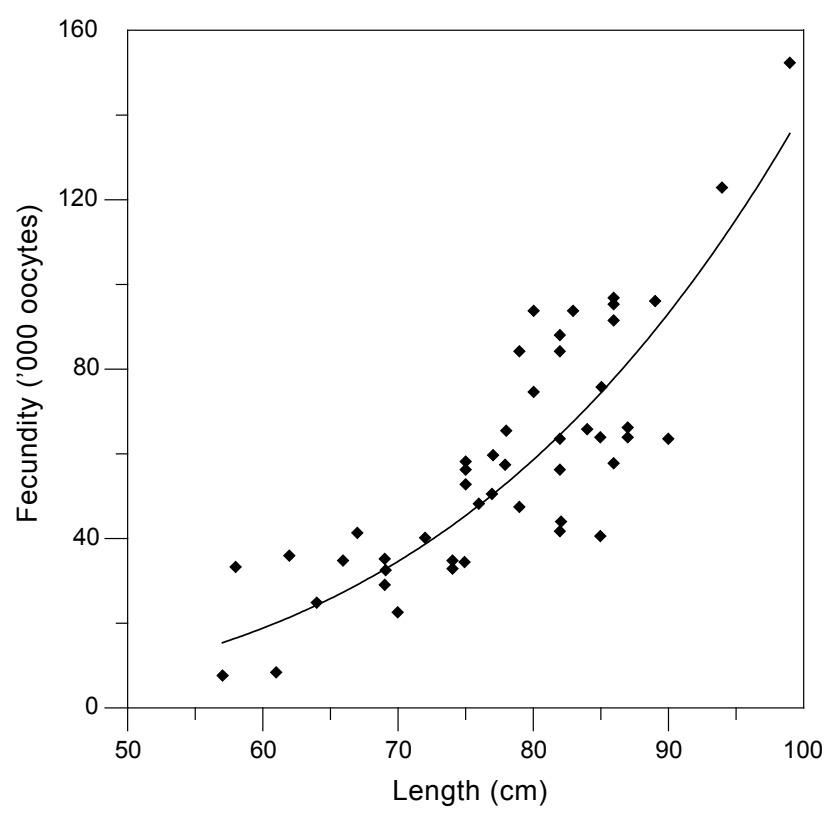

Fig. 3. Relationship between total length of Greenland halibut females and fecundity shown as the back-transformed estimated power equation. Line shows power regression.

et al., 1998; Kennedy et al., 2007; Rideout and Morgan, 2007). The extent of this variation in Greenland halibut is poorly documented.
TABLE 2. Confidence interval for the parameter estimates determined by bootstrapping.

\begin{tabular}{lcc}
\hline \multicolumn{1}{c}{ Parameter } & $\operatorname{Exp}(a)$ & $b$ \\
\hline 2.5 percentile & $1.57 \mathrm{E}-05$ & 2.81 \\
25 percentile & $3.61 \mathrm{E}-04$ & 3.51 \\
Median & $1.96 \mathrm{E}-03$ & 3.93 \\
75 percentile & $1.21 \mathrm{E}-02$ & 4.31 \\
97.5 percentile & $2.64 \mathrm{E}-01$ & 5.03 \\
\hline
\end{tabular}

Compared to the previous investigation of fecundity of Greenland halibut in Icelandic waters (Magnússon, 1977), the fecundity was much lower than in the present study. In Magnússon (1977) the oocyte diameters were 2-4 mm indicating that the fish would probably be very close to spawning (Gundersen, MS 2003). The fish in the present study were caught several months earlier, in October and it can be seen from the GSI that they are at an early stage of ovary development (Gundersen, MS 2003). This may explain the difference seen in fecundity as atresia is common in Greenland halibut and can take place throughout the maturation process (Fedorov, 1968, 1971; Walsh and Bowering, MS 1981; Junquera et al., 1999; Tuene et al., 2002; Gundersen, MS 2003; Cooper et al., 2007) so it is possible that the fecundity in the present study could have become reduced due to atresia to a level similar to that of the fish in 1977.

In comparison to the studies from other areas, it can be seen that there is variation in fecundity between areas. However, it is also apparent that there is a large variation in individuals of the same stock with the fecundity of $80 \mathrm{~cm}$ fish ranging from $40-90$ thousand eggs. This encompasses most of the range seen between stocks. This large variation appears to be a common aspect of fecundity in Greenland halibut (Gundersen et al., 2000, 2001; Cooper et al., 2007), and is in contrast to plaice, a closely related species, which show a much closer relationship between length and fecundity. Even with this large overlap in fecundity between stocks, the significant differences in the average fecundity could bring about large differences in egg production between stocks at the population level.

The population fecundity of fish stocks is known to vary from year to year due to many biotic and abiotic factors (Tanasichuk and Ware, 1987; Kennedy et al., 2007; Kjesbu et al., 1998). Potential fecundity can also vary 
with progression through ovary development (Thorsen et al., 2006). This variability limits the ability to compare fecundity between areas, especially when the fecundity estimates from the different areas are taken in different years or during different times of the year. Due to this study encompassing fecundity estimates from only one year allows us only to speculate on differences in fecundity of Greenland halibut in these different areas. It appears that significant differences exist between areas, but further investigation is needed in order to draw conclusions on whether fecundity differences are a regular feature between these stocks.

There have been many other investigations on Greenland halibut fecundity from many different areas; West Greenland (Jensen, 1935), Southern Labrador Sea (Lear, 1970) Bering Sea (D'yakov, 1978), Southern Labrador and Gulf of St. Lawrence (Bowering, 1980), and the Davis Strait near Labrador (Serebryakov et al., 1992). However, due to the mentioned variation in fecundity between years it is not possible to conclude if any there are any real differences in fecundity between any of these areas. None of these studies report any information on the progression of the gonad development of the fish which also adds another level of difficulty when comparing fecundity to previously published estimates.

\section{Acknowledgements}

This work was financed by Norwegian research council (127358 and 170690), Nordic Ministry Council (66010.021.062/99), Marine Research Institute in Iceland, and Møre Research Ålesund. The work is one of several sub-projects connected to the project "Maturity and fecundity of West-Nordic Greenland halibut". This project is a Nordic collaboration between Norway (coordinator), Greenland, Iceland and Faroe Islands. The ultimate objective of the project is to contribute to increased understanding of reproductive biology of Greenland halibut in the waters of East Greenland, Iceland and Faroe Islands. The authors want to thank technicians at the Marine Research Institute in Reykjavik and the crew on commercial Greenland halibut trawler for help during sampling and survey. Samples were analysed by Jonas P. Jonasson, Marine Research Institute, Reykjavik, Iceland.

\section{References}

BAGENAL, T. B. 1957. Annual variations in fish fecundity. J. Mar. Biol. Assoc. U.K., 36: 377-382. doi:10.1017/ S0025315400016866

1966. Ecological and geographical aspects of fecundity of plaice. J. Mar. Biol. Assoc. U.K., 46: 161-186. doi: $10.1017 / \mathrm{S} 0025315400017628$

BOJE, J., and N. R. HAREIDE. MS 1993. Trial deepwater longline fishery in the Davis Strait, May-June 1992. NAFO SCR. Doc., No. 53, Serial No. N2236, 6 p.

BOWERING, W. R. 1980. Fecundity of Greenland halibut (Reinhardtius hippoglossoides Walbaum), from southern Labrador and South-eastern Gulf of St. Lawrence. $J$. Northw. Atl. Fish. Sci., 1: 39-43.

COOPER, D. W., K. P. MASLENIKOV, and D. R. GUNDERSON. 2007. Natural mortality rate, annual fecundity, and maturity at length for Greenland halibut (Reinhardtius hippoglossoides) from the northeastern Pacific Ocean. Fish. Bull., 105: 296-304.

D'YAKOV, Y. P. 1978. The fecundity of the Greenland halibut, Reinhardtius hippoglossoides (Pleuronectidae), from the Bering Sea. J. Ichthyol., 2: 59-64.

FEDOROV, K. Y. 1968. Oogenesis and sexual maturity cycle of Greenland halibut. Trudy PINRO, 23: 425-451.

1971. The State of the gonads of the Barents Sea Greenland halibut Reinhardtius hippoglossoides (Walb.) in connection with failure to spawn. Voprosy Ichthiologii, 1: 673-682.

GUNDERSEN, A. C. 2002. Short note on fecundity of Greenland halibut in West-Greenland waters. In: Reproduction of West-Nordic Greenland halibut. A. C. Gundersen (Ed.). Tema Nord, Copenhagen, Denmark, p. 197-210.

MS 2003. Sexual maturity, fecundity and nursery grounds of Northeast Arctic Greenland halibut (Reinhardtius hippoglossoides (Walbaum)). Ph.D. Thesis, University of Bergen, Bergen, Norway.

GUNDERSEN, A. C., W. M. EMBLEM, A. H. HELLEVIK, P. STEINGRUND, and L. H. OFSTAD. 2002. Fecundity of Greenland halibut (Reinhardtius hippoglossoides) in Faroese waters, Summer 1999. In: Reproduction of WestNordic Greenland halibut. A. C. Gundersen (Ed.). Tema Nord, Copenhagen, Denmark, p. 175-196.

GUNDERSEN, A. C., O. S. KJESBU, A. STENE, and K. H. NEDREAAS, 1999. Fecundity of Northeast Arctic Greenland halibut (Reinhardtius hippoglossoides). J. Northw. Atl. Fish. Sci., 25: 29-36. doi:10.2960/J.v25.a3

GUNDERSEN, A. C., K. H. NEDREAAS, O. S. KJESBU, and O. T. ALBERT. 2000. Fecundity and recruitment variability of Northeast Arctic Greenland halibut during 1980-1998, with emphasis on 1996-1998. J. Sea Res., 44: 45-54. doi: 10.1016/S1385-1101(00)00038-1

GUNDERSEN, A. C., J. E. RØNNEBERG, and J. BOJE. 2001. Fecundity of Greenland halibut (Reinhardtius hippoglossoides) in East Greenland waters. Fish. Res., 51: 229-236. doi:10.1016/S0165-7836(01)00248-X

ICES. 2008. Report of the North-Western Working Group (NWWG). 21-29 April 2008, ICES Headquarters, Copenhagen. ICES CM 2008/ACOM:03, 604 p. http://www. ices.dk/reports/ACOM/2008/NWWG/NWWG08.pdf

JENSEN, A. S. 1935. The Greenland halibut (Reinhardtius hippoglossoides (Walb.)) it's development and migrations. Det Kongelige Danske Videnskabs Selskabs Skrifter, Naturvidenskabelig Mathematisk Afdeling, 9 (VI/4): $1-35$.

JUNQUERA, S., E. ROMÁN, X. PAZ, and G. RAMILO. 1999. 
Changes in Greenland halibut growth, condition and fecundity in the Northwest Atlantic (Flemish Pass, Flemish Cap and Southern Grand Bank). J. Northw. Atl. Fish. Sci., 25: 17-28. doi:10.2960/J.v25.a2

KENNEDY, J., P. R. WITTHAMES, and R. D. M. NASH. 2007. The concept of fecundity regulation in plaice (Pleuronectes platessa) tested on three Irish Sea spawning populations. Can. J. Fish. Aquat. Sci., 64: 587-601. doi:10.1139/F07-034

KJESBU, O. S., P. R. WITTHAMES, P. SOLEMDAL, and M. G. WALKER. 1998. Temporal variations in the fecundity of Arcto-Norwegian cod (Gadus morhua) in response to natural changes in food and temperature. J. Sea Res., 40: 303-321. doi:10.1016/S1385-1101(98)00029-X

KURITA, Y., S. MEIER and O. S. KJESBU. 2003. Oocyte growth and fecundity regulation by atresia of Atlantic herring (Clupea harengus) in relation to body condition throughout the maturation cycle. J. Sea Res., 49: 203-219. doi: 10.1016/S1385-1101(03)00004-2

LAMBERT, Y. 2008. Why should we closely monitor fecundity in marine fish populations? J. Northw. Atl. Fish. Sci., 41: 93-106. 106. doi:10.2960/J.v41.m628

LEAR, W. A. 1970. Fecundity of Greenland halibut (Reinhardtius hippoglossoides) in the Newfoundland-Labrador Area. J. Fish. Res. Board Can., 27: 1880-1882.

MAGNÚSSON, J. V. 1977. Notes on eggs and larvae of Greenland halibut at Iceland. ICES CM 1977/F:47.

MARSHALL, C. T., O. S. KJESBU, N. A. YARAGINA, P. SOLEMDAL, and O. ULLTANG. 1998. Is spawner biomass a sensitive measure of the reproductive and recruitment potential of Northeast Arctic cod? Can. J. Fish. Aquat. Sci., 55: 1766-1783. doi:10.1139/cjfas-55-7-1766

MARSHALL, C. T., L. O'BRIEN, J. TOMKIEWICZ, F. W. KOSTER, G. KRAUS, G. MARTEINSDÓTTIR, M. J. MORGAN, F. SABORIDO-RAY, J. L. BLANCHARD, D. H. SECOR, P. J. WRIGHT, N. V. MUKHINA, and H. BJORNSSON. 2003. Developing alternate indices of reproductive potential for use in fisheries management:case studies for fish stocks spanning an information gradient. J. Northw. Atl. Fish. Sci., 33: 161-190. doi:10.2960/ J.v33.a8

MARTEINSDOTTIR, G., and K. THORARINSSON. 1998. Improving the stock-recruitment relationship in Icelandic cod (Gadus morhua) by including age diversity of spawners. Can. J. Fish. Aquat. Sci., 55: 1372-1377. doi:10.1139/ cjfas-55-6-1372

MILLINSKY, G. J. 1944. On the biology and the fisheries of the Reinhardtius hippoglossoides (Walbaum) of the Barents Sea. The Bottom Food-Fishes of the Barents Sea. Pishchepromizdat, Moscow, 8: 375-387.

RIDEOUT, R. M., and M. J. Morgan. 2007. Major changes in fecundity and the effect on population egg production for three species of north-west Atlantic flatfishes. J. Fish Biol., 70: 1759-1779. 1779. doi:10.1111/j.10958649.2007.01448.x

SEREBRYAKOV, V. P, A. K. CHUMAKOV, and I. I. TEVS. 1992. Spawning stock, population fecundity and yearclass strength of Greenland halibut (Reinhardtius hippoglossoides) in the Northwest Atlantic. J. Northw. Atl. Fish. Sci., 14: 107-113.

SIGURŎSSON, A., and J. V. MAGNÚSSON. 1980. On the nursery grounds of the Greenland halibut spawning in Icelandic waters. ICES CM 1980/G:45, 8 p.

TANASICHUK, R. W., and D. M. WARE. 1987. Influence of interannual variations in winter sea temperature on fecundity and egg size in Pacific herring (Clupea harengus Pallasi). Can. J. Fish. Aquat. Sci., 44: 1485-1495. doi:10.1139/f87-178

THORSEN, A., C. T. MARSHALL, and O. S. KJESBU. 2006. Comparison of various potential fecundity models for north-east Arctic cod Gadus morhua, L. using oocyte diameter as a standardizing factor. J. Fish Biol., 69: 1709-1730. doi: 10.1111/j.1095-8649.2006.01239.x

TUENE, S., A. C. GUNDERSEN, W. EMBLEM, I. FOSSEN, J. BOJE, P. STEINGRUND, and L. H. OFSTAD. 2002. Maturation and occurrence of atresia in oocytes of Greenland halibut (Reinhardtius hippoglossoides W.) in the waters of East Greenland, Faroe Islands and Hatton Bank. In: Reproduction of West-Nordic Greenland halibut. A, C. Gundersen (Ed.). Tema Nord, Copenhagen, Denmark, p. 73-96.

WALSH, S. J., and W. R. BOWERING. MS 1981. Histological and visual observations on oogenesis and sexual maturity in Greenland halibut off Northern Labrador. NAFO Scientific Council Studies, 1: 71-75.

WITTHAMES, P. R., M. GREER WALKER, M. T. DINIS, and C. L. WHITING. 1995. The geographical variation in the potential annual fecundity of Dover sole Solea solea (L) from European shelf waters during 1991. Neth. J. Sea Res., 34: 45-58. doi:10.1016/0077-7579(95)90013-6 